\title{
Bringing the Standards of Ukrainian Banking Legislation to EU Standards
}

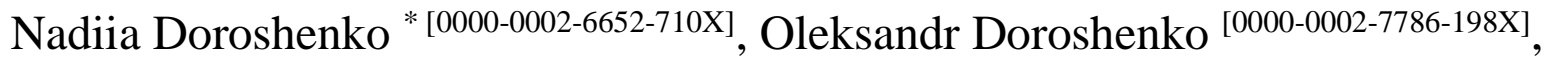 \\ Vladyslav Melnychenko [0000-0002-5064-5734]
}

\author{
V.N. Karazin Kharkiv National University, Kharkiv, Ukraine \\ *NODoroshenko@karazin.ua
}

\begin{abstract}
The banking system is an integral component and destructive force of the state economy. The implementation of new ways and principles of conducting banking business is quite dynamic under the conditions of modern globalization processes. The reform of the banking system is directly accompanied by the establishment of appropriate regulations at the legislative level, which are adapted to internationally recognized legal norms and international experience in banking. Banking should be carried out exclusively on a legal basis, and the shortcomings of the legislation directly affect the operations and condition of banks. That is why this study is based on two areas of specialties and covers the fundamentals of law and the banking system. This article is devoted to the study of the main directions of banking system development carried out by reforming the banking legislation. A number of normative legal acts of national legislation, main international agreements of Ukraine in the field of banking system reform are analyzed. We also studied the reports and action plans of the National Bank of Ukraine and the Cabinet of Ministers of Ukraine which propose the implementation of the Basic Principles of Effective Banking Supervision and provide the implementation of the Association Agreement between Ukraine on the one hand, and the European Union, the European Atomic Energy Community and their Member States on the other hand in banking. Certain legislative changes are proposed to help achieve the principles set out in the EU acquis and Basel III. On the basis of official reporting indicators an analysis of the efficiency of banks was carried out depending on the form of ownership - with public, private and foreign capital in order to establish the shortcomings of the modern domestic banking system.
\end{abstract}

Keywords. banking system, National Bank of Ukraine, reforms, principles, legislation, agreement.

\section{INTRODUCTION}

Since its independence, Ukraine has chosen the European vector of its own development. Ukraine is considering its future exclusively among the successful countries of the developing partnership and has set the European Union membership as a priority goal. It is obvious that to achieve this goal, Ukraine needs to go through a difficult path to implement the main requirements. By ratifying the Association Agreement between Ukraine, on one side, and the European Union, the European Atomic Energy Community and their Member States, on the other side (hereinafter referred to as the Association Agreement), Ukraine undertook commitments to align with European Union law and banking legislation.

The banking system is one of the most important elements in the formation and functioning of relationship between financial market entities and is an integral part of the country's financial system. First of all, this is due to the fact that banks play a crucial role in organizing the movement of large financial flows. A potent banking system promotes the efficient development of economic entities and forms the basis of a developed and stable economy.

Banks as economic entities fall under the general effect of economic laws that apply in any civil society. In order to achieve their own goals, the relationship of banks with other elements of the financial market create a unique market mechanism called the economic system.

Considering not only economic processes and political changes, but also legislative changes taking place in Ukraine, we need constant analysis and control of the banking system with the possibility of timely regulation. It is necessary to monitor changes and additions to the legal framework and compare them with the requirements of banking realities. Considering the 
necessity of rapprochement of Ukrainian legislation with the legal system of the European Union (acquis communautaire) our state must implement the low of rational reforms of Ukrainian banking legislation to the EU acquis, and this depends on the sustainable scientific basis.

\section{RESEARCH AIM AND OBJECTIVE}

The purpose of this article is to establish the main vectors of reforming the Ukrainian banking legislation in terms of the need to improve the banking system and adapt it to the European standards. In order to achieve this goal, the following tasks need to be accomplished successfully: to examine the current state of the banking system of Ukraine noting the problems and challenges of today; to identify areas for its transformation for the sustainable development of the entire system [1]; to analyze the basic laws and regulations governing the activities of Ukrainian banks and compare them with EU regulations to identify differences and gaps and propose measures to minimize their negative effects.

\section{ANALYSIS OF RECENT RESEARCH AND PUBLICATIONS}

The functioning and development of the banking system does not lose its relevance at all stages of economic development. Therefore, foreign and domestic economists have devoted their scientific lives to the study of the banking system and ways to improve it. First of all, such classics as P. Rose, D. Sinky, R. Dixon, B. Niddles, O. Vasiurenko, B. Ivasiv, L. Prymostka. Among the latest studies, the work of K.V. Vasylkivska and S.A. Rubakha (2018) on increasing the efficiency of the banking system was considered very interesting. The authors propose to limit participation of foreign capital in the Ukrainian banking system and enshrine it in law [2]. We consider this proposition to be hindered for Ukraine that strives to comply with the principles of the democratic state, as this violates the main principle of the EU banking law, i.e. the freedom of enterprises (freedom of establishment). Referring to Amit Ghosh's research, which analyzes the impact of globalization on the profitability of host banks depending on the level of development, it can be argued that the need for prudential intervention exists only in countries with low level of economic development. While in the EU, foreign banks are in healthy competition with resident banks, which helps the latter to grow [3]. N.V. Barakhtian reveals the main trends and obstacles to reforming banking legislation [4]. With each new wording, the laws of Ukraine are improved and adapted to fundamental international principles, nonetheless, the issue of compliance of legislation governing banking with modern requirements does not lose its relevance and needs control and constant study, adjusting to current changes.

\section{PRESENTING MAIN MATERIAL}

One of the most important functions of the banking system is the transformation of temporary available funds into banking resources as well as their further direction in the development of economic branches that require financial support for production and investment projects.

A significant increase in the importance of the banking system in the economic growth of any country is a feature of the modern economy. Along with the growing importance of the banking system in the economy of Ukraine, there is an objective need to create the preconditions for clear and stable legal regulation of this range of issues and adaptation to international banking law. The main legislative acts regulating the banking system in Ukraine are the Constitution of Ukraine, Laws of Ukraine "On Banks and Banking", "On the National Bank of Ukraine", "On Payment Systems and Funds Transfer in Ukraine", regulations of the National Bank of Ukraine (hereinafter NBU), etc.

Development of efficient and reliable banking system of Ukraine is one of the priorities of the NBU regulatory policy. A detailed analysis of the current state of the banking system of Ukraine shows that the basic goals, including high reliability and profitability, competitiveness, and a high level of customer confidence, unfortunately, remain unfulfilled. And it is no wonder, since the current situation is characterized by the presence of a global economic crisis, intensified by the effects of COVID-19 and the inclination to deepen European integration. The banking system of Ukraine has undergone qualitative and quantitative changes in recent years. On the one hand, they reflect positive tendencies and hopes for the system's oversight, and on the other hand, negative characteristics of the development of banking institutions, which were caused by poor regulation, weak control and lack of strict liability during the formation of banks.

As of June 1, 2021, 73 banks were operating in Ukraine, although the analysis of data for the last 10 years shows that as of January 1, 2014, their number was 180 banks (Number of banks in Ukraine, 2021) [5]. In fact, there was a sharp decline in the number of banks, the socalled "bank failure", as some of them were considered problematic, insolvent, fraudulent and those that do not provide information [6] about the final beneficiaries. To do this, the regulator had to initiate changes to twenty regulations and approve laws that helped clean up the banking system, make it clearer, which should increase public confidence in the banking sector. One of the most important ones was the Law of Ukraine "On Amendments to Certain Legislative Acts of Ukraine Regarding the Responsibility of Bank-Related Entities". It introduced criminal [7, 8] bringing the bank to insolvency. 
In order to ensure sustainable development of the banking system it is necessary to take low measures to ensure proper legal regulation and reform in the sphere of banking services. This is why the Cabinet of Ministers of Ukraine approved the Ukrainian Ministry of Finance's proposal for a Strategy for Reforming the State Banking Sector and endorsed the Principles of Strategic Reform in the State Banking Sector.

According to these principles, the main objective of public sector bank reform is to create and maintain a reliable and competitive banking system, a significant part of which is expected to become private in the future, as well as to achieve high efficiency of the entire banking sector. This objective covers several key tasks: the financial results of state-owned banks aimed at ensuring and guaranteeing their stability and long-term maximization of value; significant reduction of state concentration of Ukraine banking system. During the implementation of plans for the state to take over the ownership of banks, it is planned to reduce the part of the state in the banking sector from $55.9 \%$ at the beginning of 2021 to below than $25 \%$ by 2025 and increase their value. The state should refrain from strategic projects that require an increase in the part of the state in the financial sector, including the creation of new state-owned banks or the historical participation in the capital of banks which could increase government spending $[9,10]$.

In recent years, Ukraine's banking sector has faced a high level of financial and economic instability and a large number of borrowers who have actually defaulted on their loans. Although a part of non-performing loans (NPLs) has been gradually decreasing since 2018, as of June 1, 2021, in Ukraine it was $37.8 \%$. A part of nonperforming loans in the loan portfolio (NPL $-90 \%$ as of May 1, 2021, in comparison with banks of the Russian Federation) is the highest among state-owned banks. The highest NPL rate on the system in JSC CB "PrivatBank" - 71.8\%. But since JSC CB "PrivatBank" became stateowned only at the end of 2016, and financial problems arose earlier due to fraudulent activities of its ex-owners, these data are not indicative. However, JSC "State Savings Bank of Ukraine" has at the beginning of 2021 $45.7 \%$ of non-performing loans, JSC "Ukreximbank" $53.6 \%$. In general, banks with state capital have an NPL of $40,6 \%$. For comparison, in banks of foreign banking groups NPL is from $2.3 \%$ to $38.1 \%$ and on average on June 1, 2021 is $10.3 \%$, and in Ukrainian banks with private capital $-12.4 \%$ [11].

It is known that the National Security and Defense Council (NSDC) extended sanctions against two Russian banks (PJSC Prominvestbank NPL - 99.6\% and JSC Sberbank NPL $-84.5 \%$ ) and banned the withdrawal of capital in favor of persons related to banks. The regulator, represented by the NBU, has no legal basis for terminating the activities of Russian banks in Ukraine. But the Verkhovna Rada of Ukraine and the National
Security and Defense Council have the power to limit the presence of Russian capital. It is the people's deputies of Ukraine who must develop and approve the relevant bill and finally decide the fate of banks with Russian state capital in the Ukrainian market. This should be a principled position given both the political and the financial and economic situation.

Funds on household accounts in the national currency for the first quarter of 2021 increased in all groups of banks. Banks with private capital had the highest rates $8.9 \%$. Outflow of foreign currency funds by $1.4 \%$ was observed in Privatbank, as well as other state-owned banks $-1.7 \%$. In addition, the foreign currency of corporations increased by $6.4 \%$, and again the leaders are banks with private capital with a result of $+30.4 \%$ [12].

Analysis of the above makes it possible to establish that to reduce external influence [13] on the banking system, ensure its stability, competitiveness and efficiency there is an urgent need to develop its capacity for self-regulation, which should be realized by reducing the state's share in the banking sector. The studied data testify to the greater efficiency of non-state banks, whose policy is dynamic both in terms of reducing the number of non-performing loans and opening new accounts and attracting customer funds.

As of June 2021, there are 56 banks with foreign capital in Ukraine, including 23 foreign banks with strategic decision-making centers abroad, it can be argued that the banking sector is one of the leaders in globalization processes among other sectors of the economy. Thus, as of June, 2021, 76\% of banks had either wholly or partly foreign investors in their capital structures, but the general share of foreign capital in the Ukrainian banking system remains at about 30\% [12]. Indeed, the benefits of the presence of foreign experience and foreign cheap money are plentiful, but it would be a mistake to ignore the risks of a sharp outflow of capital and the possible loss of sovereignty of the banking system Therefore, the NBU should be especially vigilant in monitoring these risks.

Article 133 of the Association Agreement stipulates that the parties recognize the need to approximate the legislation of Ukraine to the law of the European Union [14]. Therefore, in accordance with the provisions of the Association Agreement, Ukraine has agreed to make the necessary efforts to ensure the implementation of international standards of regulation and supervision in the field of financial services and to combat tax evasion throughout its territory. Such international standards [15] include, in particular, "The Basic Principles for Effective Banking Supervision" of the Basel Committee, "The Basic Principles for Insurance" of the International Association of Insurance Supervisors, "The Forty Recommendations" and "The Nine Special Recommendations for Combating 
Terrorism Financing" of groups to develop financial measures to combat money laundering [14].

To improve its own banking legislation, Ukraine has agreed to implement the basic principles of effective banking supervision, which in fact are the minimum standards for reliable prudential regulation and supervision of banking systems.

The fundamentals are the necessary standards of reliable supervisory practice that are universally applicable. The Committee established the Basic Principles, in fact contributing to the strengthening of the global financial system. The shortcomings of the banking systems of developed or developing countries may well be a threat to financial stability both within the country and internationally. The Committee is convinced that the implementation of the Basic Principles by all countries will be an important step towards strengthening financial stability at both the national and international levels, while providing a good basis for the sustainable development of efficient supervisory systems [16].

Analysis of the NBU's reporting allows us to examine the measures taken to implement the basic European principles, as well as the principles of effective banking supervision. First, an effective banking supervision system requires the establishment of clear responsibilities for each agency involved in the banking supervision process, as well as measures to improve the level of corporate governance in banks. To address these issues, the Law of Ukraine "On Amendments to Certain Legislative Acts of Ukraine on Improving Corporate Governance in Banks and Other Issues of the Functioning of the Banking System" was developed and adopted on June 30, 2021 and approved by IMF experts. It is provided for clarification and expansion of the powers of the NBU and the solution of those issues that need to be addressed for a long time. In particular, for a long time there was an urgent need in Ukraine to clarify the powers of the National Bank of Ukraine in the field of banking supervision on a consolidated basis, to establish the bank's right to assess the availability of the required level of qualifications and ability [17] to organize based on the results of such assessment is to require replacement of the board or board of the bank in case of their inability to ensure effective control and management of the bank within its powers [18]. The adoption of this Law is a very important step in bringing our legislation in line with best practices in the organization of corporate governance and risk management [19] system in banks.

At the same time, it is noteworthy that the focus on reforming the management of state-owned banks, ensuring compliance of banking supervision with best practices, the course to reduce the share of the state in the banking sector are set out in the Memorandum of Economic and Financial Policy of June 2, 2020, this vector is unacceptable [20].
The European course of Ukraine's banking sector development presupposes the need to refer to the EU legal acts that regulate the functioning of the banking system for implementation of their basic provisions that will serve as a guarantee for adaptation of Ukrainian banking legislation to the EU law. Thus, article 9 of the Directive of the European Parliament and the Council on initiation and fulfillment of activity of credit institutions dated 14.06.2006 provides that without damage to other general conditions laid down by national law, competent authorities may not grant a license if credit institutions do not have separate own funds or in cases where their initial capital is less than five million euros [21]. The same applies to Directive $97 / 5 / \mathrm{EU}$ to Chapter II of the Regulation on Foreign Currency Transfers by order and for the benefit of individuals [22]. We consider that it would be quite appropriate to propose this provision in the legislation of Ukraine, because it will contribute to the stability of the existence of both a particular bank and the banking system.

Clearly aware of the essence of liberal values, Ukraine has followed the European tradition of human rights protection. That is why Article 129 of the Association Agreement stipulates that each party allows a financial service provider of the other party to transmit information electronically or otherwise in its territory or outside it for data processing purposes, if such processing is necessary in the normal course of such provider. Each party shall take adequate special measures to protect the right to privacy and fundamental human rights and freedoms, regarding the transfer of personal data [14].

Due to the need of protecting the confidential information, including personal data, the basic principles of efficient banking supervision have enshrined the principle of cooperation and collaboration, which provides that laws, regulations or other mechanisms provide a basis for cooperation and collaboration with relevant internal authorities and foreign supervisors [16].

The National Bank of Ukraine, the National Commission on Securities and Stock Market, the Ministry of Finance of Ukraine and the Deposit Guarantee Fund formed the Financial Sector Development Strategy of Ukraine till 2025 (hereinafter the Strategy), according to which an important task in the financial sector reform, and particularly in the banking system, is to increase the level of public confidence from $10 \%$ by 2025 to $60 \%$. The Disclosure Index is also set to improve to 5.0, including the presence of a number of disclosure requirements, up to 5.0. The goals of the Strategy are to promote sustainable economic growth of Ukraine, achievement of macro-financial stability, increase the reliability and manufacturability of the financial system, implement European standards in the financial market, increase confidence in the financial market, implement the Association Agreement and other international treaties of our country [23]. 
That is, the strategy for the banking legislation development should be the increase of the level of protection of human rights and increase of the financial awareness, which will be a prerequisite for increasing confidence in the banking system and improving the level of investment attractiveness.

\section{CONCLUSION AND PROSPECTS FOR FURTHER RESEARCH}

During the research on the main statistical data on the efficiency of banks, it was found that in Ukraine there is an urgent need to increase the productivity of the banking system. In particular, there is a fairly high level of nonperforming loans and a lower level of profitability in state-owned banks (compared to private and foreign banks). The solution to this problem consists in reducing the state's participation in the banking sector and implementing this issue on the ground by making the appropriate changes to Ukraine's legislation. At the same time, the quantitative limits of foreign capital presence in the banking system should not be established, as it will be indicative of the prescriptive nature of the banking system regulation and violation of the EU acquis. The NBU must operate with quality indicators, timely control over the activities of all banks and the ability to respond immediately. In this way a competitive, stable, and customer-oriented banking system can be implemented.

The analysis of international treaties of Ukraine, the most significant of which is the Association Agreement, indicates the orientation of our country towards implementation of European standards in the banking system. As a rule, implementation of all provisions of this agreement is one of the biggest challenges for Ukraine today. That is why there is a need to develop projects and adopt a number of regulations on implementation of the Basel Core Principles, such as the Law of Ukraine "On Amendments to Certain Legislative Acts of Ukraine for Improving the Organization of Corporate Governance in Banks and Other Issues of the Banking System". This Law was adopted on June 30, 2021, which is indirectly aimed at implementing certain principles of effective banking supervision (supervision method and tools, supervision reporting) and clearly demonstrates the intention and direction of Ukraine's activity on reforming the banking legislation.

One of the problems of Ukraine's current banking system is a rather low level of public confidence. In our opinion, the solution to this issue should provide a course for the liberalization of the banking system, which is directly aimed at ensuring the protection of human rights increasing the level of protection of information about persons that constitutes banking secrecy. We consider its observance as a necessary condition for increasing the level of public confidence in the entire financial system and improving the level of investment attractiveness.
Thus, adaptation to European law is coming slowly, sometimes with resistance and problems, but we hope that scientific developments, including our research, will become a worthy foundation for practical action. And step by step, without changing directions, Ukraine will become a full member of the EU, and banking legislation will comply with international standards.

Modern legislation is dynamic and is often undergoing changes. Therefore, we consider it necessary to carry out further research on the main directions of reforming banking legislation to understand the vector of its development, awareness of all the problems and challenges of today. This topic is quite relevant and therefore we are confident that our scientific work opens new horizons for further research on this issue.

\section{REFERENCES}

[1] Kotlyarevsky, Ya.V. Melnychenko, A.A. Ivanytska, O.M. Semenyuk, E.P. Kniaziev, S.I. and Melnikov, O.V. (2020), "New Economy: Evolution of Forms and Research Methodology", Sci. Innov., vol 16, no. 1, pp. 15-30, DOI: $10.15407 /$ scine 16.01 .015 .

[2] Vaskivska, K.V. Rubakha, S.A. (2018), "Directions for enhancing the efficiency of functioning of the Ukrainian banking system", The Young Scientist, vol. 11 (63), pp. 1077-1080, available at: http://nbuv.gov.ua/UJRN/molv_2018_11\%282\%2 9_137

[3] Ghosh, A. (2016), "Banking sector globalization and bank performance: A comparative analysis of low income countries with emerging markets and advanced economies", Review of Development Finance, vol. 6, pp. 58-70, available at: https://www.sciencedirect.com/science/article/pii/ S1879933716300367

[4] Barakhtian, N.V. (2017), "Reforming banking legislation: main trends and obstacles", Legal scientific electronic journal, pp. 58-60, available at: http://lsej.org.ua/5_2017/16.pdf

[5] Ministry of Finance of Ukraine (2021), "Number of banks in Ukraine", available at: https://index.minfin.com.ua/ua/banks/stat/count/20 21/

[6] Semenyuk, E.P. Kotlyarevsky, Ya.V. Kniaziev, S.I. and Melnikov, O.V. (2017), "Information Economy: the Formation of Special-Purpose Categorical Framework", Sci. Innov., vol. 13, no. 3, pp. 5-19, DOI: 10.15407/scine13.03.005.

[7] Korystin, O.Y. Nekrasov, V.A. Krivolapchuk, V.O. and Sviridyuk, N.P. (2019), "The Phenomenology of Money Laundering in Ukraine", Financial and credit activities: problems of theory and practice, 
vol. 2 (29), pp. 374-382, DOI: 10.18371/fcaptp.v2i29.171949

[8] Korystin, O.Y. Svyrydiuk, N.P. Mihus, I.P. Likhovitskyy, Y.O. and Mitina, O.M. (2020), "Money laundering: macroeconomic assessment methods and current trend in Ukraine", Financial and credit activities: problems of theory and practice, vol. 1 (32), pp. 341-350, DOI: 10.18371/fcaptp.v1i32.200865

[9] Framework for Strategic Reform of the State Bank Sector (Strategic Principles) (2020), available at: https://mof.gov.ua/storage/files/20200814\%20SO B\%20Strategy.pdf

[10] Korystin, O.Ye. (2020), Chapter 4. State Legal Police of Scientific Prediction. Public administration in the digital economy, monograph, Tallinn, Scientific Center of Innovative Researches OU, DOI: 10.36690 PADE

[11] National Bank of Ukraine (2021), "Level of nonperforming loans", available at: https://bank.gov.ua/ua/stability/npl

[12] National Bank of Ukraine (2021), "Overview of the banking sector", available at: https://bank.gov.ua/admin_uploads/article/Bankin g_Sector_Review_2021-05.pdf?v=4

[13] Senthilkumar, K. (2018), “The Influence of Emotional Factors in the Purchase of Children Products and Brands", International Journal of Education and Management Engineering, vol. 8, no. 5, pp. 18-30, DOI: 10.5815/ijeme.2018.05.03

[14] Association Agreement between Ukraine, on the one hand, and the European Union, the European Atomic Energy Community and their Member States, on the other hand (2014), no. 984_011, n.d. 6, pp. 124-133

[15] Muhammad, H. and Zedan, Hesham A. Hassan (2013), "An Aligned Assessment Item Authoring Environment based on Interoperability Standards", IJMECS, vol. 5, no. 12, pp. 1-9, DOI: $10.5815 /$ ijmecs.2013.12.01
[16] Core Principles for Effective Banking Supervision (Basel Core Principles) (2012), available at: https://bank.gov.ua/admin_uploads/article/Basel_ Core_principles_2012.pdf

[17] Samuel Ndichu, Sylvester McOyowo, Henry Okoyo and Cyrus Wekesa, "A Remote Access Security Model based on Vulnerability Management", International Journal of Information Technology and Computer Science, Vol.12, No.5, pp.38-51, 2020, DOI: 10.5815/ijitcs.2020.05.03

[18] Draft Law on Amendments to Certain Legislative Acts of Ukraine to Improve the Organization of Corporate Governance in Banks and Other Issues of the Banking System Functioning № 4367 (2020).

[19] I Gede Ary Suta Sanjaya, Gusti Made Arya Sasmita and Dewa Made Sri Arsa (2020), "Information Technology Risk Management Using ISO 31000 Based on ISSAF Framework Penetration Testing (Case Study: Election Commission of X City)", International Journal of Computer Network and Information Security, vol. 12, no. 4, pp. 30-40, DOI: $10.5815 /$ ijcnis.2020.04.03

[20] Ministry of Finance of Ukraine (2021), "Memorandum on economic and financial policy", available at: https://mof.gov.ua/uk/memorandum of_economic_and_financial_policies_by_the_auth orities_of_ukraine-435

[21] European Parliament and Council Directive on the initiation and operation of credit institutions, no. 994_862 rev. II Art. 6 (2006).

[22] Directive 97/5/EC to Part II of the Regulation on Foreign Currency Transfers by order and for the benefit of natural persons, no 994_276 (1997).

[23] National Bank of Ukraine (2021), "Development of the financial sector", available at: https://bank.gov.ua/ua/about/develop-strategy 